\title{
Ammonia and gasoline composite liquid fuel blends emulsified with ethanol and methanol for direct displacement in internal combustion engines
}

\author{
Shehan O. Haputhanthri ${ }^{1}$, Chad Austin ${ }^{2}$, Timothy Maxwell ${ }^{1}$, John Fleming ${ }^{3}$ \\ ${ }^{\prime}$ (Department of Mechanical Engineering, Texas Tech University, Lubbock, Texas, USA) \\ ${ }_{2}^{2}$ (Ford Motor Company, Allen Park, Michigan, USA) \\ ${ }^{3}$ (Silver Eagles Energy LLC, Lubbock, Texas, USA)
}

\begin{abstract}
Ammonia, when blended with hydro carbon fuels, can be used as a composite fuel to power existing IC engines using the hydrogen energy contains in the chemical. Such blends, similar to ethanol and gasoline fuel blends can be used to commercialize ammonia as an alternative fuel. Feasibility of developing ammonia gasoline liquid fuel blends and the use of ethanol and methanol as emulsifiers to enhance the solubility of ammonia in gasoline were studied using thermostated vapor liquid equilibrium (VLE) high pressure cells, in this research. A small VLE cell was used to quantify the solubility of ammonia in gasoline more accurately and a larger VLE cell was used to develop identified fuel blends in sufficient quantities for engine dynamometer tests. A SuperFlow model 902 engine dynamometer with a GM family II Ecotec LE5 2.4L gasoline engine was used to benchmark performance of ammonia fuel blends against standard fuels. Solubility test results prove that emulsifier free pure gasoline is capable of dissolving $23 \mathrm{~g} / \mathrm{l}$ of ammonia on mass basis $(4.5 \%$ of ammonia on volume basis) at 50 Psi pressure and $286.65 \mathrm{~K}$ temperature in liquid phase. Solubility level is increased with the use of ethanol and methanol. Gasoline with $10 \%$ ethanol can retain $51.4 \mathrm{~g} / \mathrm{l}$ (11.0\% on volume basis) of ammonia in the liquid phase at the same pressure and temperature. Methanol has better emulsifying capabilities. Solubility level of gasoline with $10 \%$ methanol is $61.8 \mathrm{~g} / \mathrm{l}$ (11.0\% on volume basis). Dynamometer results show the ability of new composite fuel blends to produce the same amount of torque and power in the lower rpm limits. At higher rpm levels ammonia rich fuels result in an increased torque and power. Thus it can be concluded that hydrogen energy can be stored as ammonia-gasoline fuel blends and recovered back successfully without any strenuous modification to the existing infrastructure and end user equipment or behavior.
\end{abstract}

Keywords : Ammonia, Ethanol, Gasoline, Methanol, Fuel blends, Alternative transport fuel

\section{INTRODUCTION}

The combined future volumes of conventional petroleum, heavy oil, oil sands and oil shale total 29.9 trillion barrels of oil equivalent (BOE). At a production growth rate of 5 percent, conventional petroleum and heavy oil resources will last only 51 years as assessed in 2009[1]. Therefore, an alternate for petroleum fuel should be identified without delay. Hydrogen energy is a carbon free sustainable energy source which can be used as an alternative to depleting petroleum reserves. Numerous studies have been conducted to assess the feasibility of hydrogen energy technologies [2-4].

Ammonia is a substantial hydrogen carrier which can be used as a storage method of hydrogen energy [3-5]. Anhydrous ammonia is a compound containing one atom of nitrogen and three atoms of hydrogen (NH3). Ammonia contains about 17 percent by weight of hydrogen, which is much better than all other non-carbon based hydrogen storage methods. Industrially, anhydrous ammonia is usually supplied as liquid at about $150 \mathrm{psi}$ at ambient temperature. Thus, ammonia has a huge potential to be used as an alternative for petroleum fuels.

Dual ammonia-diesel fuel systems for CI engines and ammonia-gasoline fuel systems for SI engines have been studied in the literature extensively [6-10]. These studies use methods such as dual fuel storage systems which inject ammonia in to the combustion chamber at the point of injection or on-board catalytic reforming of hydrogen from ammonia. Two major drawbacks of these proposed systems in commercializing ammonia in the short term are the vehicular modifications and strenuous infrastructure. To overcome these disadvantages ammonia can be blended into the liquid phase of gasoline.

Ammonia, when blended with hydro carbon fuels, can be used as a composite fuel to power existing IC engines. Such blends, similar to ethanol and gasoline fuel blends can be used to commercialize ammonia as an alternative fuel which does not require end user equipment (vehicular) modifications or infrastructure changes. This research is focused on developing gasoline-ammonia liquid fuel blends which can be used in existing IC engines. 
The static-analytic method is an accepted method used in the literature for gas solubility measurements in liquids. High pressure borosilicate glass view cells or high pressure thermostated vapor liquid equilibria (VLE) cells are the apparatus used for this research [11-14]. VLE cells are used in this research to measure the solubility of gaseous ammonia in liquid gasoline. A small stainless steel VLE cell was constructed quantify the solubility and identify the suitable emulsifiers for gasoline and ammonia composite fuel blends and to quantify the solubility levels. A larger thermostated VLE cell was used to produce proven blends in large quantities for the engine dynamometer tests.

Ammonia is a polarized molecule and gasoline is a non-polarized molecule with a long carbon chain. This reduces the solubility of ammonia in gasoline. Emulsifiers or cross linkers with non-polarized and polarized parts in the molecule, can be used to enhance the solubility under this situation. Ethanol and methanol have both polarized (OH-) and non-polarized $\left(-\mathrm{C}_{2} \mathrm{H}_{5} /-\mathrm{CH}_{3}\right)$ molecular structure. Thus it can be used as an emulsifier to enhance the solubility of ammonia in hydrocarbon fuels. Solubility of ammonia in ethyl alcohol was estimated to be $85 \mathrm{~g} / \mathrm{l}$ in atmospheric pressure and $293.15 \mathrm{~K}[15]$. It was experimentally proven that the solubility of ammonia in the liquid phase of pure ethanol is $120 \mathrm{~g} / \mathrm{l}$ at $45.2 \mathrm{Psi}$ and $208.75 \mathrm{~K}$ [11]. Due to the higher polarity and shorter carbon chain methanol has higher emulsifying capabilities. Literature shows the solubility of ammonia in pure methanol is $258.1 \mathrm{~g} / \mathrm{l}$ at $44.7 \mathrm{Psi}$ and $313.75 \mathrm{~K}$ [12]. Despite the merits and demerits of ethanol and methanol they are used in the automotive industry as a transportation fuel[16]. Therefore both ethanol and methanol can be used as economically feasible emulsifiers for ammonia-gasoline fuel blends.

A SuperFlow 902 engine dynamometer with a GM family II Ecotec LE5 2.4L gasoline engine was used in the research to benchmark the performance of the ammonia fuel blends against standard fuels. Better performances are observed when the ammonia rich fuels are benchmarked against baseline fuel especially at higher engine speeds.

\section{MATERIALS AND MeTHODS}

Emulsifier free pure gasoline, gasoline with $10 \%$ ethanol and gasoline with $10 \%$ methanol were selected for the study (named as E0, E10 and M10 respectively). Pure gasoline was purchased from United Farm Supplies, Plainview, TX. ACS grade 200 proof ethanol and methanol were purchased from Pharmaco Apper Products CT via Texas Tech University Chemistry Department. 99\% pure ammonia was purchased from Pure Gas LLC.

Out of the two methods used in the static gas analysis, VLE cell method was used to measure the solubility of gaseous ammonia in liquid gasoline. Figure 1 shows an image of small VLE cell with a capacity of $1500 \mathrm{~cm} 3$ equipped with mixer, pressure transducer and thermocouple. The capacity of larger VLE cell is 20500 $\mathrm{cm} 3$.

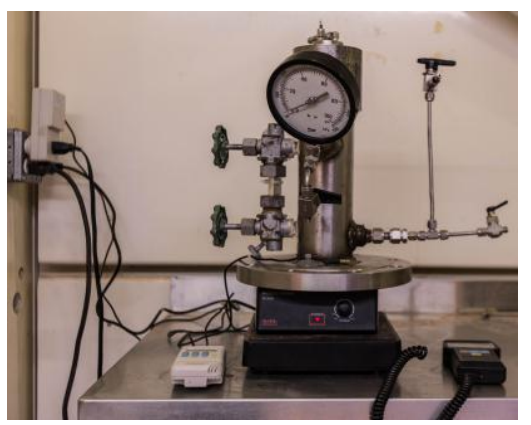

Figure 01 Small thermostated VLE cell

Two cells are exactly identical to each other except for the capacity and method of mixing. The small cell uses a magnetic mixer while the large cell uses an impeller driven by an external motor for mixing. The impeller shaft is secured with a cup-seal to prevent gas leaks. A borosilicate gauge glass is fixed to a side of the tanks to measure the liquid level. The larger cell was used to prepare feasible composite fuel blends in large quantities for engine dynamometer testing. The equipment was tested and calibrated according to the standard mentioned in literature[12,13]. Figure 2 shows a schematic diagram of VLE cell.

Model AST4000 pressure transducers with and accuracy of 0.25 Psi were purchased from American Sensor Technologies Incorporation. Bourdon tube pressure gauges purchased from Marshall Instruments USA were also used to verify the pressure indicated by pressure transducers. They were calibrated against a dead weight pressure calibrator for better accuracy. K type thermocouple thermometers and a model 52II reader from Fluke Corporation were used in the experiment. The accuracy of these thermocouples was rated to be $0.3 \mathrm{~K}$.

A charging cell, made of stainless steel was first filled with ammonia from a larger ammonia feed stock tank. VLE cells were degassed using a vacuum pump and then filled with known amount of gasoline variant, thermostated to the desired temperature. The experiment was carried out inside a thermostated chamber. System 
was agitated and allowed to come to equilibrium. The weight, pressure and the temperature of the thermostated charging cell were recorded and a known amount of ammonia was bubbled through the liquid in small steps until the pressure of the system reached 10 psi. System was agitated and allowed to come to equilibrium. After the equilibrium state was reached, the liquid volume, temperature, pressure and weight of the charging cell were recorded.

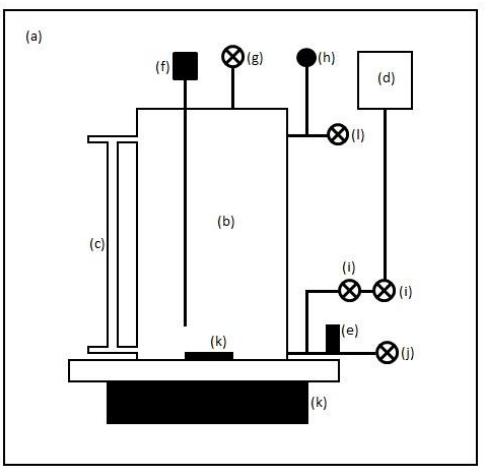

Figure 02 Schematic diagram of the small thermostated VLE cell (a) thermostated chamber (b) VLE cell (c) borosilicate gage glass for liquid level measurements (d) ammonia charging tank (e) pressure transducer (f) K type thermocouple thermometer $(\mathrm{g})$ relief valve $(\mathrm{h})$ bourdon tube pressure gage (i) charging tank connection valves (j) liquid feed in valve $(\mathrm{k})$ magnetically coupled mixer (l) auxiliary valve for gas chromatography

The total volume of the tank was known from the initial measurements. The volume of the vapor phase was calculated by subtracting the liquid volume from the total volume of the tank. The pressure in the vapor phase was considered to be totally created by the added ammonia escaped to the vapor phase of the system to the system at the particular room temperature. The mass of ammonia in the vapor phase was calculated for the corresponding state (temperature and pressure) using the software package (NIST)[17]. The mass of the ammonia in the liquid was then calculated by subtracting the mass of the ammonia in the vapor phase from the total mass of the ammonia added to the system. The volume of the connection tube was known and corrections were applied for the ammonia loss from the tubing connection.

This process was repeated until the pressure reached 50 Psi in 10 Psi increments. For the large cell, due to the nature of pressure transducer, measurements were taken at 12.5 Psi increments. Margin of error in liquid level measurements was calculated to be less than $1.5 \%$. The experimental data were recorded three times per each sample to ensure the repeatability. Maximum margin of error of overall recorded results was estimated to be less than $3 \%$. Temperature of the thermostated chamber was maintained to an accuracy of $1 \mathrm{~K}$.

Percentage volume increase and solubility levels were calculated with respect to the initial fuel volume and weight. For the molality calculations density of the ethanol-gasoline solutions were calculated by measuring the weight of known volume of the solutions.

Figure 3 shows the engine dynamo-meter setup used for the experiment. A SuperFlow 902 engine dynamometer was used to test actual performance of the fuel blends produced. A GM family II Ecotec LE5 2.4L four cylinder SI engine with factory controls and all the hardware unchanged, was used to benchmark the performance of fuel blends. Engine specifications are mentioned in Table 01.

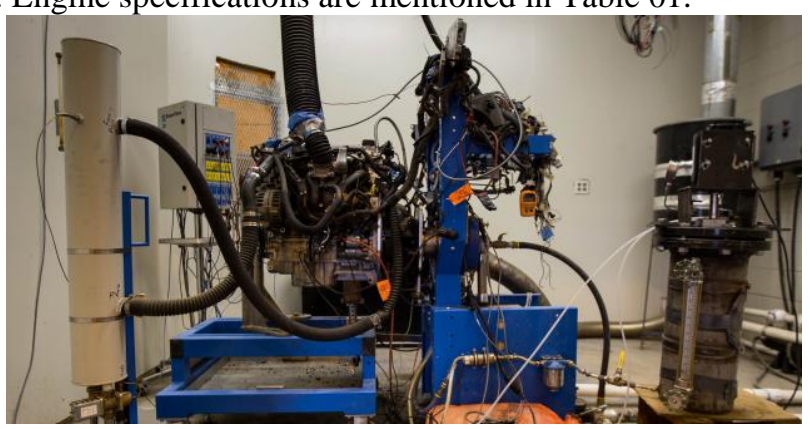

Figure 03 SuperFlow 902 engine dynamometer with Eco-Tec LE5 2.4L engine

Five tests were carried out for each fuel blend and the average is then calculated to avoid any discrepancy. The test profile was designed to start at 1900 RPM, increase the engine speed to 2000 RPM in 5 seconds and then speed up the engine from 2000 to $5000 \mathrm{rpm}$ in 15 seconds. All the tests were carried out at full throttle position. Data was recorded in 0.25 seconds increments. The maximum engine speed used in the test was 5000 RPM. First dynamometer baseline tests without any added ammonia were conducted for each gasoline variant (E0, E10 and M10). Then dynamometer tests were carried out using the gasoline variants with known concentrations 
of ammonia. Tests for comparison of baseline fuel with ammonia rich fuel were carried out at the same time, under similar environmental and engine conditions. Dynamometer performance results of composite fuel blends were then compared against the baseline blends.

Table 01 Specifications of Ecotec LE5 engine

\begin{tabular}{|l|l|}
\hline Parameter & Value \\
\hline Displacement & $2384 \mathrm{CC}$ \\
\hline Bore X Stroke & 88.00 X $98.00(\mathrm{~mm})$ \\
\hline Fuel System & Sequential fuel injection (Port injection) \\
\hline Compression ratio & $10.4: 1$ \\
\hline Peak power & $169 \mathrm{hp}$ at $6400 \mathrm{RPM}$ \\
\hline Peak torque & $160 \mathrm{lb}-\mathrm{ft}$ at $4500 \mathrm{RPM}$ \\
\hline Peak engine speed & $6750 \mathrm{RPM}$ \\
\hline CAM & DOHC with VVT \\
\hline
\end{tabular}

\section{RESULTS}

Solubility tests using the small cell were carried out in a thermostated chamber . $286.15 \mathrm{~K}$ with accuracy of $1 \mathrm{~K}$ was selected as the reference temperature for the tests. A summary of the small VLE cell measurements are presented in tables 2 .

Table 02 Change of solubility, percentage volume increase, and molality with pressure at $286.15 \mathrm{~K}$

\begin{tabular}{|c|c|c|c|c|c|c|c|c|c|}
\hline \multirow{2}{*}{$\begin{array}{l}\text { Pressure } \\
\text { (Psi) }\end{array}$} & \multicolumn{3}{|c|}{ E0 } & \multicolumn{3}{|c|}{ E10 } & \multicolumn{3}{|c|}{ M10 } \\
\hline & $\begin{array}{c}\text { Solubility } \\
(\mathrm{g} / \mathrm{l})\end{array}$ & $\begin{array}{c}\text { Vol. Inc. } \\
(\%)\end{array}$ & $\begin{array}{l}\text { Molality } \\
\text { (mol/kg) }\end{array}$ & $\begin{array}{c}\text { Solubility } \\
(\mathrm{g} / \mathrm{l})\end{array}$ & $\begin{array}{c}\text { Vol. Inc. } \\
(\%)\end{array}$ & $\begin{array}{l}\text { Molality } \\
\text { (mol/kg) }\end{array}$ & $\begin{array}{c}\text { Solubility } \\
(\mathrm{g} / \mathrm{l})\end{array}$ & $\begin{array}{c}\text { Vol. Inc. } \\
(\%)\end{array}$ & $\begin{array}{l}\text { Molality } \\
(\mathrm{mol} / \mathrm{kg})\end{array}$ \\
\hline 10 & 0.90 & 0.90 & 0.07 & 8.42 & 1.84 & 0.66 & 13.99 & 1.84 & 1.08 \\
\hline 20 & 1.95 & 1.81 & 0.15 & 16.85 & 4.60 & 1.32 & 27.98 & 3.68 & 2.16 \\
\hline 30 & 6.56 & 2.71 & 0.50 & 25.27 & 6.44 & 1.97 & 38.25 & 5.52 & 2.95 \\
\hline 40 & 11.16 & 3.61 & 0.86 & 37.42 & 8.73 & 2.92 & 50.41 & 8.72 & 3.89 \\
\hline 50 & 23.04 & 4.51 & 1.77 & 51.43 & 11.03 & 4.02 & 68.14 & 11.03 & 5.26 \\
\hline
\end{tabular}

The relationships between pressure and molality, and pressure and solubility can be interpreted as exponential while percentage volume increase maintains a linear relationship with pressure. Figure 4 graphically represents the data tabulated in the previous table.

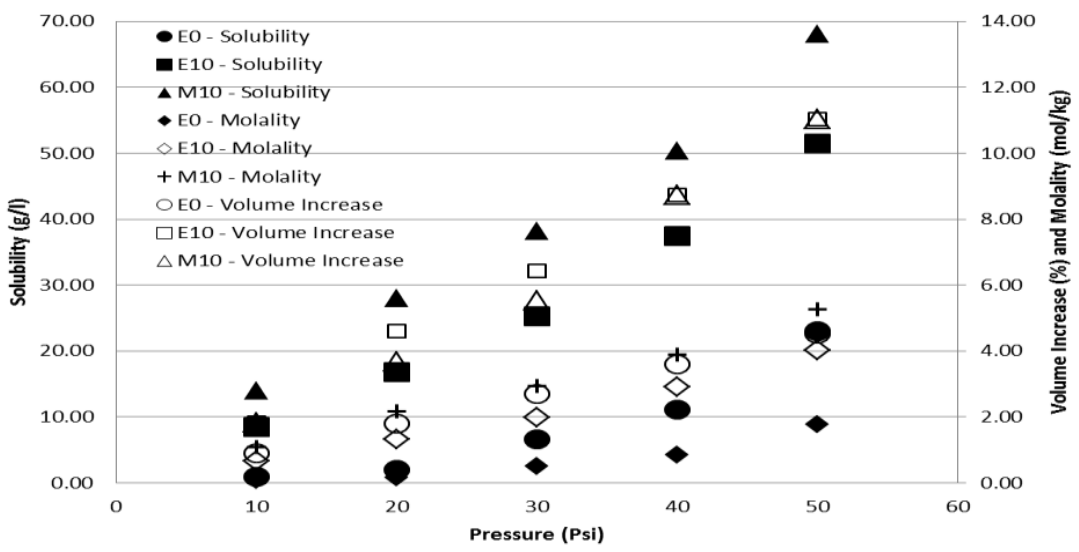

Figure 04 Change of solubility, percentage volume increase, and molality with pressure at $286.15 \mathrm{~K}$

The thermostated chamber was not large enough to accommodate the large VLE cell and the actual dynamometer tests were carried out in ambient conditions. Therefore blending for dynamometer tests were carried out at the ambient temperature of that particular day of the test. Solubility levels of the actual test fuel differ from what was measured using small cell due to the temperature variation. A summary of the actual test fuels are given in the Table 03. A comparison test was carried out to verify the accuracy of large VLE cell against small VLE cell at similar temperatures. The deviation of results was under $3 \%$. The dynamometer test for E10 was carried out at 30 Psi pressure. Due to the lower pressure level, solubility level of blend used for the E10 dynamometer test was also lower. 
Table 03 Details of fuel blends used for the dynamometer tests (50 Psi)

\begin{tabular}{|l|r|r|r|}
\hline Fuel Blend & \multicolumn{1}{l|}{ E0 } & \multicolumn{1}{l|}{ E10 } & \multicolumn{1}{l|}{ M10 } \\
\hline Temperature (K) & 293.65 & 298.15 & 293.15 \\
\hline Pressure (Psi) & 50 & 30 & 50 \\
\hline Solubility (g/l) & 19.06 & 31.65 & 67.5 \\
\hline Volume Increase (\%) & 3.74 & 5.65 & 11.5 \\
\hline Molality (mol/kg) & 1.52 & 2.48 & 5.23 \\
\hline
\end{tabular}

Figures 6-8 show the actual test results for power and torque curves for each baseline fuel and ammonia rich fuel.

The average percentage difference of power between E0 and E0A3.74 is $1.29 \%$ over the entire run and only $0.54 \%$ from 3300-5000 RPM, which are negligible differences. Therefore it can be assumed that both fuels behaved similarly due to the low ammonia content in the fuel.

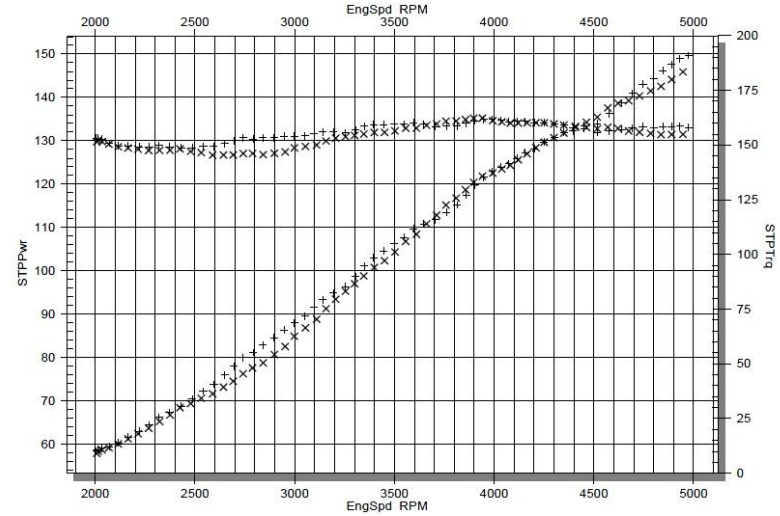

Figure 06 Power and torque curves of E0 and E0A3.74 (+-+: E0, x-x: E0A3.74)

During the complete run E10A5.65 produces more torque and power when compared to E10. Results were almost identical at lower engine speeds though after the 3500 RPM level, E10A5.65 produces more torque and power. The maximum power and torque differences between two fuels are $12.9 \mathrm{hp}$ and $9.9 \mathrm{ft}-1 \mathrm{bs}$ respectively, both were in favor of E10A5.65. The resulting power and torque curves of E10 and E10A5.65 are shown in Figure 07.

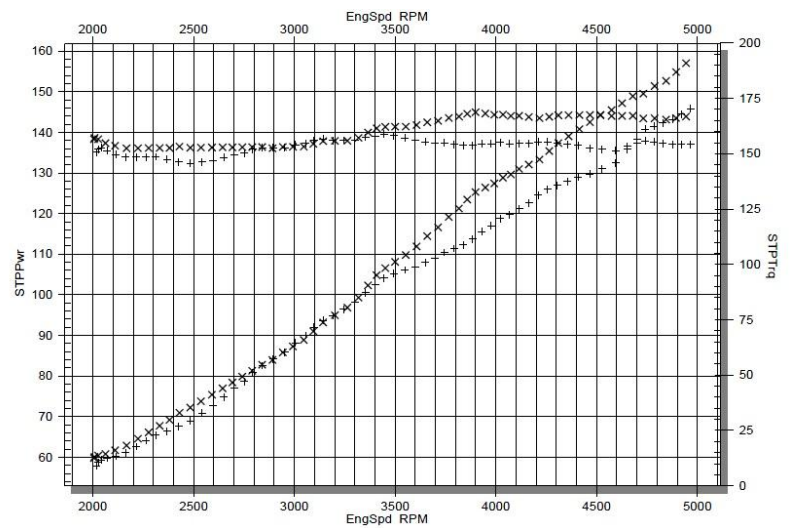

Figure 07 Power and torque curves of E10 and E10A5.65 (+-+: E10, x-x: E10A5.65)

M10A11.5 produces similar results to E10. Results were almost identical at lower engine speeds. After 3500 RPM level, M10A11.50 produces more torque and power. The maximum power and torque differences between two fuels are $5.5 \mathrm{hp}$ and $7.1 \mathrm{ft}-\mathrm{lbs}$ respectively, both in favor of M10A11.50. 


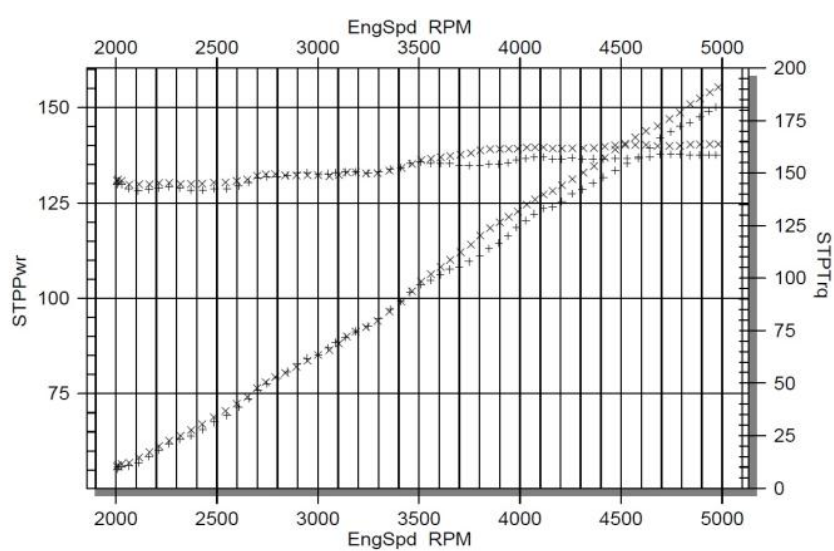

Figure 08 Power and torque curves of M10 and M10A11.50 (+-+: E10, x-x: M10A11.50)

IV.

\section{DISCUSSION}

The feasibility of storing pure hydrogen in the liquid phase of gasoline was studied using the available literature data. Due to the unavailability of data for hydrogen solubility in gasoline, data for hydrogen solubility in alcohols reported in the literature were used[18, 19]. Table 06 summarizes the data reported in [18] for hydrogen solubility in ethanol and methanol.

Table 06 Solubility of hydrogen in ethanol and methanol at $291 \mathrm{~K}[18]$

\begin{tabular}{|r|c|r|r|r|r|}
\hline \multicolumn{3}{|c|}{ Methanol } & \multicolumn{3}{c|}{ Ethanol } \\
\hline $\begin{array}{c}\text { Pressure } \\
(\mathrm{MPa})\end{array}$ & $\begin{array}{c}\text { Pressure } \\
(\mathrm{Psi})\end{array}$ & Mole fraction & $\begin{array}{c}\text { Pressure } \\
(\mathrm{MPa})\end{array}$ & $\begin{array}{c}\text { Pressure } \\
(\mathrm{Psi})\end{array}$ & Mole fraction \\
\hline 1.1 & 159.5 & 0.0018 & 1.39 & 201.6 & 0.0031 \\
\hline 1.6 & 232.1 & 0.0026 & 2.18 & 316.2 & 0.0050 \\
\hline 2.6 & 377.1 & 0.0044 & 2.56 & 371.3 & 0.0057 \\
\hline 3.1 & 449.6 & 0.0052 & 3.12 & 452.5 & 0.0067 \\
\hline 3.62 & 525.0 & 0.0061 & & & \\
\hline
\end{tabular}

The solubility of pure hydrogen in alcohols is very low compared the solubility of ammonia in alcohols. Due to the molecular structure of gasoline compared to ethanol and methanol the solubility level of hydrogen in gasoline is expected to be even lower than this. These solubility levels are not substantial enough to store a considerable amount of hydrogen energy in the liquid phase of gasoline to make the blend economically viable. Thus solubility of hydrogen in gasoline was not studied in the research. Solubility of ammonia in ethanol and methanol has been studied in the literature at various temperatures and pressures [11, 12, 15]. Figure 09 summarizes the data reported in [11,12] for ammonia solubility in ethanol and methanol. Molecular structure and the higher polarity can be considered as the primary reasons for higher solubility of ammonia methanol than that of ammonia in ethanol. Experimental results from this research obey this behavior for the solubility of ammonia in gasoline - ethanol/methanol solutions.

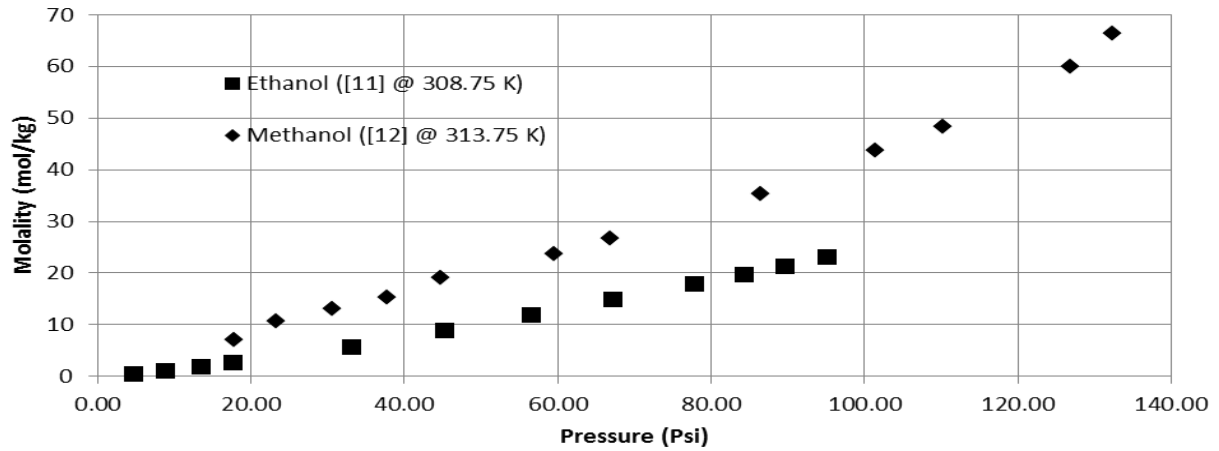

Figure 09 Solubility of ammonia in ethanol and methanol as reported in literature $[11,12]$

The solubility of ammonia in pure gasoline is not sufficient to make ammonia blends feasible to use. It can be enhanced with the use of alcohols as emulsifiers in gasoline. Engine performances remain constant or improve with the addition of ammonia to the combustion chamber as a fuel. Table 04 summarizes the engine dynamometer results. Power and torque value variation between baseline tests were observed due to the change 
of the fuel pump. However power and torque curves were consistent throughout comparison tests between baseline fuel and corresponding ammonia rich fuel. All the tests for comparison were carried out in similar engine and environmental conditions.

Table 07 Summary of dynamometer test data for E0, E10A5.65 and M10A11.5

\begin{tabular}{|l|r|r|r|r|r|r|}
\hline & \multicolumn{1}{|c|}{ E0 } & E0A3.74 & \multicolumn{1}{c|}{ E10 } & E10A5.65 & \multicolumn{1}{c|}{ M10 } & M10A11.50 \\
\hline Peak power (hp) & 149.6 & 145.9 & 145.9 & 157 & 150.1 & 155.3 \\
\hline Peak power RPM & 4974 & 4946 & 4966 & 4944 & 4971 & 4981 \\
\hline Peak torque (ft-lbs) & 161.8 & 162.3 & 158.8 & 168.7 & 159 & 163.8 \\
\hline Peak torque RPM & 3950 & 3900 & 3345 & 3899 & 4746 & 4981 \\
\hline Power gain with ammonia (hp) & \multicolumn{3}{|c|}{-3.7} & \multicolumn{7}{|c|}{12.9} & & 5.5 \\
\hline Torque gain with ammonia (ft-lbs) & \multicolumn{7}{|c|}{9.9} & \multicolumn{2}{|c|}{7.1} \\
\hline
\end{tabular}

The octane rating of ammonia is relatively higher than that of gasoline[5]. Thus ammonia and gasoline blends have a higher octane rating than pure gasoline. In general cooling power of an internal combustion engine is estimated to be $7.2 \%$ of the engine power [6]. Higher specific heat capacity of ammonia can help to reduce the combustion temperature inside the combustion chamber which results in lower cooling power. These factors can be considered as the reasons for increase in power and torque levels and decrease in exhaust temperature particularly at higher engine speeds[6]. Engine knocking issues can be expected to be eliminated with the increased octane number. Thus better compression ratios can be utilized for ammonia rich fuels.

\section{CONCLUSION}

With a suitable emulsifier ammonia can be dissolved in hydrocarbon fuels in sufficient quantities such that it can be used as an alternate transport fuel. Ethanol and methanol which are already being used as fuel for internal combustion engines and fuel additives[20], are suitable emulsifiers for the ammonia hydrocarbon liquid fuel blends. Engine performances do not alter with the introduction of ammonia to the fuel. At higher engine speeds ammonia rich fuels perform better than corresponding baseline fuels

Emissions characteristics and fuel consumption characteristics of the ammonia blends remains to be studied further to draw a complete conclusion about the fuel blends. According to the literature ordinary threeway catalytic converters and exhaust gas oxygen sensors can be used to clean up emissions from ammoniagasoline dual fuelled spark ignition engines [21]. Following the same argument emissions from these liquid fuel blends should be easily handled in existing ordinary vehicles. Also effects of the temperature on the stability of the fuel blend have to be investigated further. Once this is completed areas such as custom engine controls for the ammonia gasoline fuel blends and combustion chamber optimization for a quality burn etc. can be studied in depth. Though existing engine management systems are capable of handling ammonia to a certain extent, control algorithms and some hardware should be upgraded for blends with higher ammonia percentages. Similar study has to be carried out for diesel to identify the feasibility of ammonia-diesel fuel blends.

It can be concluded that hydrogen energy can be stored as ammonia-gasoline composite liquid fuel blends and stored energy can also be recovered back as a transportation fuel for existing internal combustion engines. Strenuous modification to the existing infrastructure and end user equipment or behavior is not required as ammonia already is a widely used chemical with well-developed processes and methods for ammonia production, storage and handling.

\section{REFERENCES}

[1] R. F. Aguilera, R. G. Eggert, G. L. C. C, and J. E. Tilton, "Depletion and the Future Availability of Petroleum Resources," Energy Journal, vol. 30, pp. 141-174, 2009

[2] K. B. Martin and S. E. Grasman, "An assessment of wind-hydrogen systems for light duty vehicles," International Journal of Hydrogen Energy, vol. 34, pp. 6581-6588, 2009.

[3] C. H. Christensen, T. Johannessen, R. Z. Sørensen, and J. K. Nørskov, "Towards an ammonia-mediated hydrogen economy?," Catalysis Today, vol. 111, pp. 140-144, 2006.

[4] R. Lan, J. T. Irvine, and S. Tao, "Ammonia and related chemicals as potential indirect hydrogen storage materials," International Journal of Hydrogen Energy, vol. 37, pp. 1482-1494, 2012.

[5] C. Zamfirescu and I. Dincer, "Ammonia as a green fuel and hydrogen source for vehicular applications," Fuel Processing Technology, vol. 90, pp. 729-737, 2009.

[6] C. Zamfirescu and I. Dincer, "Using ammonia as a sustainable fuel," Journal of Power Sources, vol. 185, pp. 459-465, 2008.

[7] C. Duynslaegher, H. Jeanmart, and J. Vandooren, "Kinetics in Ammonia-Containing Premixed Flames and a Preliminary Investigation of Their Use as Fuel in Spark Ignition Engines," Combustion Science and Technology, vol. 181, pp. 1092-1106, 2009.

[8] A. J. Reiter and S.-C. Kong, "Combustion and emissions characteristics of compression-ignition engine using dual ammonia-diesel fuel," Fuel, vol. 90, pp. 87-97, 2011.

[9] S. Frigo and R. Gentili, "Analysis of the behaviour of a 4-stroke Si engine fuelled with ammonia and hydrogen," International Journal of Hydrogen Energy, vol. 38, pp. 1607-1615, 2013. 
[10] C. S. Mørch, A. Bjerre, M. P. Gøttrup, S. C. Sorenson, and J. Schramm, "Ammonia/hydrogen mixtures in an SI-engine: engine performance and analysis of a proposed fuel system," Fuel, vol. 90, pp. 854-864, 2011.

[11] L.-J. Huang, W.-L. Xue, and Z.-X. Zeng, "The Solubility of ammonia in ethanol between 277.35 K and 328.15 K," Fluid Phase Equilibria, vol. 303, pp. 80-84, 2011.

[12] D. Schäfer, J. Xia, M. Vogt, Á. Pérez-Salado Kamps, and G. Maurer, "Experimental investigation of the solubility of ammonia in methanol," Journal of Chemical \& Engineering Data, vol. 52, pp. 1653-1659, 2007.

[13] U. Göppert and G. Maurer, "Vapor-liquid equilibria in aqueous solutions of ammonia and carbon dioxide at temperatures between 333 and $393 \mathrm{~K}$ and pressures up to $7 \mathrm{MPa}$," Fluid Phase Equilibria, vol. 41, pp. 153-185, 1988.

[14] J. Xia, M. Jödecke, Á. Pérez-Salado Kamps, and G. Maurer, "Solubility of CO2 in (CH3OH+ H2O)," Journal of Chemical \& Engineering Data, vol. 49, pp. 1756-1759, 2004.

[15] A. Seidell and W. F. Linke, Solubilities of Inorganic and Organic Compounds: A Compilation of Solubility Data from the Periodical Literature. Supplement: Van Nostrand, 1952.

[16] J. MARSZAŁEK and W. KAMIŃSKI, "Environmental impact of bioethanol production," Proceedings of ECOpole, vol. 2, 2008.

[17] E. W. Lemmon, M. L. Huber, and M. O. McLinden, " NIST Standard Reference Database 23: Reference Fluid Thermodynamic and Transport Properties-REFPROP, Version 9.1," ed. Gaithersburg: National Institute of Standards and Technology, Standard Reference Data Program, 2013

[18] M. S. Wainwright, T. Ahn, D. L. Trimm, and N. W. Cant, "Solubility of hydrogen in alcohols and esters," Journal of Chemical and Engineering Data, vol. 32, pp. 22-24, 1987

[19] Q. Liu, F. Takemura, and A. Yabe, "Solubility of hydrogen in liquid methanol and methyl formate at $20 \mathrm{C}$ to $140 \mathrm{C}$," Journal of Chemical \& Engineering Data, vol. 41, pp. 1141-1143, 1996.

[20] M. Al-Hasan, "Effect of ethanol-unleaded gasoline blends on engine performance and exhaust emission," Energy Conversion and Management, vol. 44, pp. 1547-1561, 2003.

[21] S. M. Grannell, D. N. Assanis, D. E. Gillespie, and S. V. Bohac, "Exhaust emissions from a stoichiometric, ammonia and gasoline dual fueled spark ignition engine," in ASME 2009 Internal Combustion Engine Division Spring Technical Conference, 2009, pp. $135-141$ 